\title{
AMYLASE mRNA SYNTHESIS AND AGEING IN RAT PAROTID GLANDS FOLLOWING ISOPROTERENOL-STIMULATED SECRETION
}

\author{
S. K. KIM ${ }^{1.2 .3}$, L. M. CUzzorT ${ }^{2}$ and R. K. MCKEAN ${ }^{2}$ \\ 'Research Service, V. A. Medical Center, Ann Arbor, MI 48105 and Departments of ${ }^{2}$ Anatomy and Cell \\ Biology, Medical School and ${ }^{3}$ Biologic and Material Sciences, School of Dentistry, University of \\ Michigan, Ann Arbor, MI 48109, U.S.A.
}

\section{(Accepted 13 November 1991)}

\begin{abstract}
Summary - In the parotid, as well as in other exocrine glands, secretory protein synthesis declines with age. However, whether this decline in the steady-state rate of protein synthesis reflects the reduced digestive activity of the animal or actual cellular alterations that affect synthesis is unknown. Here the ability to synthesize amylase and its mRNA during the period of enhanced protein synthesis following secretion induced by isoproterenol was compared in acinar cells of 2-and 24-month-old rats. In unstimulated glands, rates of synthesis of total protein and amylase, as well as amounts of amylase mRNA, were significantly less in the older rats than in their younger counterparts. After stimulation with isoproterenol, which induced the secretion of about $50 \%$ of stored proteins, rates of synthesis of total protein, as well as amylase, were increased by about $2.5 \times$ the unstimulated rates in both age groups. However, the amount of amylase mRNA did not increase in parallel with the increase in the rate of amylase protein synthesis in both young and old rats. The molecular size of the mRNA was the same in stimulated and unstimulated glands of both age groups. Thus, it appears that parotid acinar cells from old rats can be stimulated to synthesize secretory proteins at an increased rate. It remains to be determined what causes the reduced rate of protein synthesis in unstimulated glands in old rats.
\end{abstract}

Key words: ageing, amylase mRNA synthesis.

\section{INTRODUCTION}

One major cell function that is affected during ageing in many organs and tissues is protein biosynthesis. Age-related declines in rates of protein biosynthesis have been demonstrated in many organs of laboratory rodents, such as the liver, muscle, brain, heart, testis and kidney [see Richardson (1981) for review]. We have shown that rates of synthesis of secretory proteins, especially $\alpha$-amylase, decline with age in rat parotid salivary glands (Kim et al., 1980, 1982; Kim, 1981; Kim and Arisumi, 1985). This decline does not appear to be related to structural alterations in the cells (Kim, 1984). However, the cause of this age-related decline in protein synthesis is unknown, as is whether or not it is due to intrinsic cellular changes.

The decline in secretory protein synthesis in exocrine, digestive glands such as the parotid could reflect the animal's reduced digestive activity rather than any cellular alteration related to ageing. In the acinar cells of the parotid, as in other exocrine glands, newly synthesized proteins are processed, packaged and stored for secretion (Castle, Jamieson and Palade, 1972; Palade, 1975). The accumulation of stored secretory proteins in the gland, if due to reduced digestive activity, could suppress the syn-

Abbreviation: SSC, standard sodium citrate. thesis of more of these proteins. In fact, the rate of protein synthesis increases in glands after stimulated discharge of stored proteins. The parotid glands can be stimulated to secrete by $\beta$-agonists, such as isoproterenol or adrenaline (Bdolah and Schramm, 1965; Babad et al., 1967; Amsterdam, Ohad and Schramm, 1969; Malamud, 1972; Lillie and Han, 1973). A single injection of isoproterenol $(8 \mathrm{mg} / \mathrm{kg}$ body weight) induces discharge of $99 \%$ of stored secretory proteins within $2 \mathrm{~h}$ in rat parotid glands. After this secretion, rates of incorporation of amino acids into acid-precipitable protein and amylase increase signiticantly ( $2.5 \times$ the unstimulated level) in $6 \mathrm{~h}$ (Lillie and Han, 1973). Thus, isoproterenol-stinn Ilated parotid glands of the rat provide an excel!ent system for comparing the effects of ageing on the rate of secretory protein synthesis in glands that are devoid of any stored proteins.

We have shown that the partial secretion of proteins induced by stimulation with a low dose of isoproterenol $(0.4 \mathrm{mg} / \mathrm{kg}$ body weight $)$ also increases the rate of post-secretory protein synthesis to about the same extent as after a near-total secretion by stimulation with a much higher dose (Kim, Jones and Cuzzort, 1989). We have now compared the agerelated differences in rates of synthesis of total protein and amylase, and the amounts of available amylase mRNA in parotid glands, after a partial secretion of glandular proteins stimulated with the lower dose of isoproterenol. 


\section{MATERIALS AND METHODS}

Rats

Male Sprague-Dawley rats of two different age groups were obtained from Harlan Sprague Dawley Inc. (Indianapolis, IN, U.S.A.). Young rats were about 2 months of age and weighed $200-250 \mathrm{~g}$; old rats were about 24 months old and weighed $450-650 \mathrm{~g}$. The rats were housed in a building that provides an environment of constant temperature and 12-h cycles of day and night. Food was witheld for about $16 \mathrm{~h}$ before experiments but drinking water was available during this period. All experiments began at 8:00 a.m.

To induce discharge of stored proteins, rats were injected intraperitoneally with isoproterenol (Sigma, St Louis, MO, U.S.A.) dissolved in saline, at a dosage of $0.4 \mathrm{mg} / \mathrm{kg}$ body weight, which induces secretion of about $50 \%$ of stored proteins (Kim et al., 1989). The dosage of isoproterenol ( $8 \mathrm{mg} / \mathrm{kg}$ body weight) that induced secretion of $99 \%$ of parotid secretory proteins in young rats could not be used because some 24-monthold rats died after injection of this large dose. The control group was injected with saline only. The rats were killed at various times after the injection by cardiac puncture under light methoxyflura ne anaesthesia.

\section{Amylase assays}

Parotid amylase was determined by its activity according to Bernfeld (1955), using starch as the substrate, and comparisons were based on the DNA content of the gland, as described by Kim et al. (1989). The DNA content was determined by the diphenylamine method of Burton (1956).

\section{Radioactive amino acid incorporation}

Rats were injected with $1 \mu \mathrm{Ci} / \mathrm{g}$ body weight of $\left[4,5-{ }^{3} \mathrm{H}\right]$-labelled L-leucine $(40 \mathrm{Ci} / \mathrm{mmol})$, (ICN Radiochemicals, Irvine, CA, U.S.A.), and killed $30 \mathrm{~min}$ later. Parotid glands were removed, cleaned of connective tissue and fat, and homogenized in distilled water. The homogenate was divided for various assays. Two samples of $1 \mathrm{ml}$ each were precipitated with $0.3 \mathrm{~N}$ perchloric acid to separate acid-soluble and -insoluble fractions (Kim et al., 1980; Kim and Arisumi, 1985). The amount of radioactivity incorporated into the acid-insoluble precipitate was measured in a Beckman LS9800 scintillation spectrophotometer after solubilizing in NCS (Amersham, Chicago, IL, U.S.A.).

The incorporation values were corrected for differences in the size and specific radioactivity of the free leucine pool to ensure that rates of leucine incorporation were not affected by changes in the size of the intracellular precursor pool. The specific activity of the precursor pool was determined as described by Kim and Arisumi (1985).

To compare rates of synthesis of secretory proteins, the incorporation of the label into amylase was measured (Kim and Arisumi, 1985). Amylase was precipitated with glycogen (Loyter and Schramm, 1962) from the samples of the gland homogenate for measurement of radioactivity by scintillation spectrometry. Rates of $\left[{ }^{3} \mathrm{H}\right]$-leucine incorporation into the acid-insoluble fraction and amylase were also compared, based on the tissue DNA content.

\section{RNA extraction, Northern and dot-blot analysis}

The procedures for RNA extraction and Northern and dot blots were similar to those described by $\mathrm{Kim}$ et al. $(1989,1990)$. The procedure was a modification of that described by Chirgwin et al. (1979). Only the RNA samples that showed two sharp ribosomal RNA bands after resolution by electrophoresis on agarose gel (Sambrook, Fritsch and Maniatis, 1989) were used for further studies. The ratio of $A_{260} / A_{280}$ of the RNA samples ranged from 1.8 to 2.14 and the DNA contamination was less than $1 \%$.

For Northern blots, RNA samples were denatured with formaldehyde, resolved by electrophoresis on $2.2 \mathrm{M}$ formaldehyde- $1 \%$ agarose gel into different sizes, and transferred to nitrocellulose filters (Sambrook et al., 1989). The filters were washed in $3 \times$ SSC (standard sodium citrate: $0.15 \mathrm{M}$ sodium chloride and $0.015 \mathrm{M}$ sodium citrate), air dried, and haked for $3-4 \mathrm{~h}$ at $80^{\circ} \mathrm{C}$. under vacuum to affix the RNA to the filter. After hybridization (described below), autoradiographs were prepared using XOMAT-AR film (Kodak, Rochester, NY, U.S.A.).

For the quantification of mRNA by dot-blot analysis, RNA samples were diluted, denatured as described above, and applied to nitrocellulose filters using a Minifold I (Schleicher and Schuell, Keene, NH, U.S.A.) as a guide. The filters were dried and baked for $2 \mathrm{~h}$. After hybridization, the dots were cut out and radioactivity was measured in a Beckman scintillation spectrophotometer (LS 9800). Each blot included RNA samples from all experimental groups in order to carry out hybridization under the same conditions using the same probe.

\section{Probe generation and determination of saturating concentration}

Hybridization was done with antisense cRNA riboprobes generated from a commercially available kit (Promega Biotech, Madison, WI, U.S.A.), as described by Kim et al. $(1989,1990)$. Hybridization was done overnight at $55^{\circ} \mathrm{C}$ under the saturating probe concentration described previously. Blots were then rinsed three times $(1,5$ and 10 min each) with a solution containing $2 \times \mathrm{SSC}$ and $0.1 \%$ sodium dodecyl sulphate) at room temperature $\left(23-25^{\circ} \mathrm{C}\right)$. Blots were further washed twice in a solution of $0.1 \times \mathrm{SSC}$ and $0.1 \%$ sodium dodecyl sulphate at $55^{\circ} \mathrm{C}$ for $30 \mathrm{~min}$, and once more at $65^{\circ} \mathrm{C}$ for $30 \mathrm{~min}$.

\section{Statistical analysis}

The statistical significance of differences between means of two samples was determined by unpaired $t$-test. A $p$ value of less than 0.05 was considered to be statistically significant. The statistical significance was also determined by the Mann-Whitney twosample test, which is the non-parametric analogue of the parametric unpaired $t$-test. Both tests were done with the statistical software package, NCSS (Hintze, 1986). The results from these two tests were not different.

\section{RESULTS}

As was expected from our previous studies (Kim et al., 1989), the concentration of parotid 


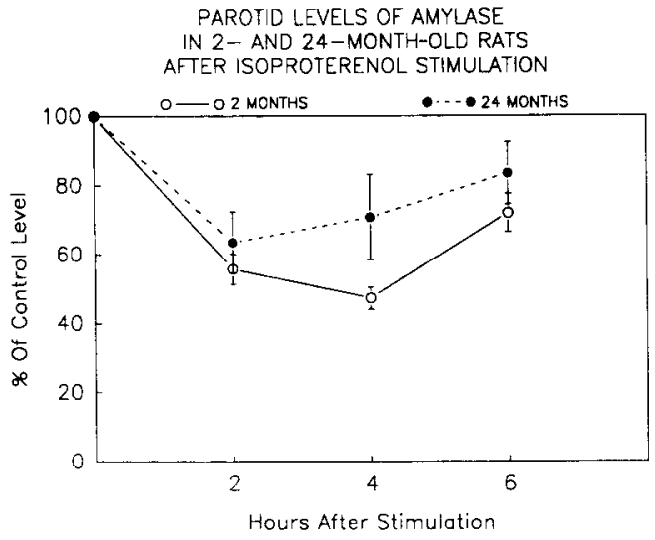

Fig. 1. Amylase content of parotid glands from young and old rats at various times after stimulation with isoproterenol. The enzyme content, determined by its activity, is shown as the percentage of the control (unstimulated) level. All values are means and SEM from at least three separate determinations.

amylase was reduced after isoproterenol injection. In stimulated parotid glands the amylase contents were reduced to 55 and $63 \%$ of their corresponding unstimulated levels in $2 \mathrm{~h}$ in young and old rats, respectively (Text Fig. 1). In old rats the amylase content increased steadily to $83 \%$ of the prestimulation level in $6 \mathrm{~h}$ after stimulation. The parotid amylase in younger rats did not begin to increase until $4 \mathrm{~h}$ after stimulation and reached $72 \%$ of the prestimulation level in $6 \mathrm{~h}$.

Rates of total protein and amylase synthesis, as determined by incorporation of $\left[{ }^{3} \mathrm{H}\right]$-leucine into total acid-precipitable or glycogen-precipitable materials, increased similarly in young and old groups after stimulation with isoproterenol. In both groups, the rate of incorporation after stimulation, adjusted by the specific radioactivity of the intracellular leucine pool, was increased by about 2.5 times over the control values at $6 \mathrm{~h}$ (Table 1 ).

However, the amount of amylase mRNA did not increase in parallel with the increase in the amino acid

Table 1. Rate of $\left[{ }^{3} \mathrm{H}\right]$-leucine incorporation into total protein and amylase in parotid glands of young and old rats before and after isoproterenol stimulation

\begin{tabular}{lcc}
\hline & $\begin{array}{c}\text { Radioactivity } \\
\text { in total protein }\end{array}$ & $\begin{array}{c}\text { \% Radioactivity } \\
\text { in amylase }\end{array}$ \\
\hline Young & & \\
Unstim & $3.00 \pm 0.40$ & $15.93 \pm 0.92$ \\
6h & $8.10 \pm 0.74$ & $17.43 \pm 1.40$ \\
Old & & \\
Unstim & $2.37 \pm 0.57$ & $13.20 \pm 1.18$ \\
$6 \mathrm{~h}$ & $6.34 \pm 0.86$ & $15.77 \pm 0.49$ \\
\hline
\end{tabular}

$6 \mathrm{~h}: 6 \mathrm{~h}$ after the injection of isoproterenol $(0.4 \mathrm{mg} / \mathrm{kg}$ body weight)

*Numbers represent mean values of dis/min per $\mathrm{mg}$ $D N A \times 10^{-2}$ per $h$ and SEs of means from three separate determinations. These incorporation values were corrected by the differences in the specific activity of the intracellular leucine pool ( $\mathrm{cpm} / \mathrm{nmol}$ leucine) calculated from three separate assays.

The values for the stimulated rats in each age group were significantly different $(P \leq 0.05)$ from those of the respective unstimulated rats.

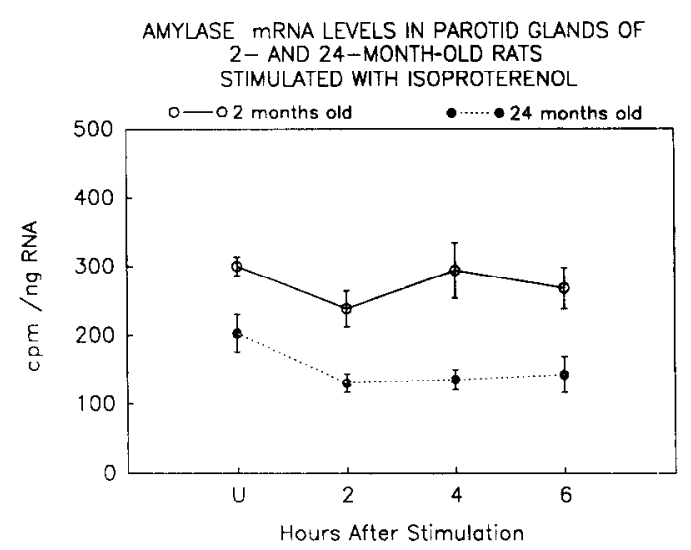

Fig. 2. Parotid amylase $m R N A$ in young and old rats before and after stimulation with isoproterenol. The mRNA was determined by radioactivity counting of dot blots (counts $/ \mathrm{min} / \mathrm{ng}$ ) of total RNA from unstimulated (U) and stimulated glands 2, 4 and $6 \mathrm{~h}$ after isoproterenol injection, hybridized with ${ }^{32} \mathrm{P}$-labelled amylase riboprobe. All values are means and SEM from three to eight determinations.

incorporation in stimulated glands of both age groups. The amount of amylase mRNA in unstimulated rats was significantly lower (by about $30 \%$ ) in the older than the younger rats (Text Fig. 2). Although the amount of amylase mRNA appeared to fluctuate somewhat in isoproterenol-stimulated rats in both age groups, the difference in the glandular contents of the mRNA between the two age groups was maintained even after stimulation. There was no significant difference in the amount of actin mRNA in stimulated and unstimulated glands of young and old rats (Text Fig. 3). Northern blots showed that the molecular size of amylase mRNA in parotid glands was the same in young and old rats and was not altered after isoproterenol stimulation (Plate Fig. 4).

\section{DISCUSSION}

Rates of total protein and amylase synthesis in unstimulated glands of older rats were less than in those of their younger counterparts, as shown previously (Kim, 1981; Kim et al., 1980, 1982; Kim and

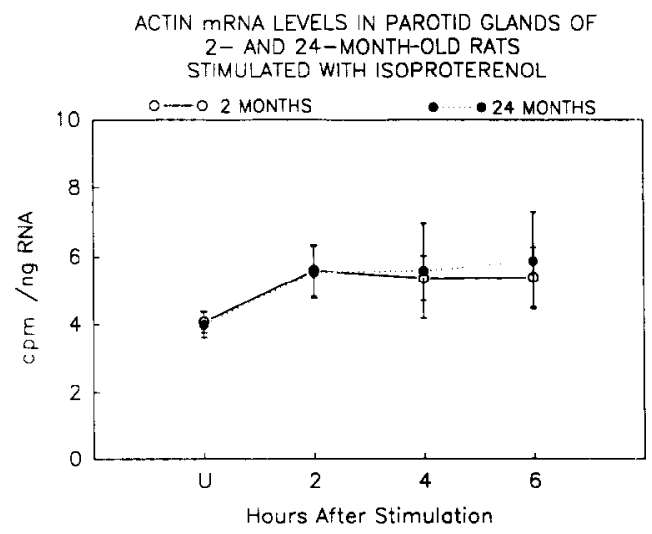

Fig. 3. Parotid actin mRNA in young and old rats before and after stimulation with isoproterenol. The mRNA was determined as described in the legend for Fig. 2 after hybridization with ${ }^{32} \mathrm{P}$-labelled actin riboprobe. 
Arisumi, 1985). The amount of amylase mRNA was also reduced in unstimulated glands of older rats, and this difference between the two age groups was maintained in isoproterenol-stimulated glands. In contrast, there was no statistically significant difference in the amount of actin mRNA present in stimulated and unstimulated glands of young and old rats. The amylase mRNAs present at various times afte isoproterenol-stimulation were of one molecular size, which was the same as in unstimulated glands (Plate Fig. 4). Thus, it is likely that the mRNA in the parotid after stimulation is functionally mature amylase mRNA. The reduction in the amount of amylase mRNA in unstimulated glands of older rats may represent the regulatory mechanism for secretory protein synthesis compensating for the decreased level of digestive activity. However, it is also possible that the reduced amount of amylase mRNA in older rats is related to intrinsic cellular alterations that affect transcription of the amylase gene.

We found that the ability of parotid acinar cells to secrete and subsequently synthesize more proteins in response to isoproterenol stimulation does not decline with age. Stimulation with $0.4 \mathrm{mg} / \mathrm{kg}$ isoproterenol induced secretion of about $50 \%$ of parotid proteins in both age groups, as shown by the reduction in the glandular amylase.

We have earlier shown that rates of synthesis of total protein, as well as amylase, increase to about $2.5 \times$ the unstimulated rate in young rats $6 \mathrm{~h}$ after a partial secretion induced by stimulation with this low dose of isoproterenol. This stimulated increase is about the extent of increase in protein synthesis in rat parotid glands that follows near total secretion induced by stimulation with a much higher $(8.0 \mathrm{mg} / \mathrm{kg})$ dose (Lillie and Han, 1973; Kim et al., 1989). Unexpectedly, however, the rates of post-secretory synthesis of these proteins also increased by about 2.5-fold over the unstimulated level in parotid glands of old rats. Thus, it appears that the rate of postsecretory protein synthesis increases to its maximum level after the stimulated discharge of part or all of stored proteins in parotid glands of both young and old rats. Then, the results indicate that parotid acinar cells in old rats can be stimulated to synthesize secretory proteins at an increased rate, as occurs in acinar cells in younger rats.

These findings contradict the many reports that the cellular ability to synthesize proteins declines with age in many organs (Richardson, 1981), including those of our earlier studies of unstimulated rat parotid glands mentioned above (Kim, 1981; Kim and Arisumi, 1985; Kim et al., 1980, 1982). The ability to adapt to changes in external physiological stresses also appears to decline with age. For example, the amount of pancreatic amylase increases in young rats when the diet is changed to a complex carbohydrate one, whereas this change does not have any signifi- cant effect on the amylase level in old rats (Greenberg and Holt, 1986).

The cellular mechanisms involved in increasing the rate of secretory protein synthesis after isoproterenolstimulated secretion are unknown. However, the rate of synthesis of each protein is generally regulated by the available amount of corresponding mRNA (Lodish, 1976). During the development of the parotid gland (Poulsen et al., 1986; Shaw, Sordat and Schibler, 1986) and pancreas (Przybyla et al., 1979), there is a parallel increase in rates of synthesis of amylase and accumulation of amylase mRNA. However, the amounts of amylase mRNA do not change in parallel with the changes in rates of amylase protein synthesis in isoproterenol-stimulated parotid glands, as shown in our earlier study of young rats; (Kim et al., 1989), as well as in young and old rats here.

There are several possible explanations for this discrepancy in the rate of protein synthesis and amount of amylase mRNA. The steady-state concentrations of mRNA species are dependent on rates of synthesis, turnover, or both. As we proposed (Kim et al., 1989), it is possible that the turnover rate of amylase mRNA is greater in isoproterenol-stimulated than in unstimulated glands. Apparently, the rate of degradation of some species of mRNA changes in response to altered physiological signals, such as hormone induction in animals (Guyette, Matusik and Rosen, 1979; Brock and Shapiro, 1983), or changes in growth rate in bacteria (Nilsson et al., 1984). Alternatively, it is also possible that the mRNA available in stimulated glands is much more efficient in its translational activity than the mRNA counterpart in unstimulated glands. It has been demonstrated that modifications, such as cap and cap-methylation at the $5^{\prime}$ terminus increase mRNA translatability (Kozak, 1980; Cordell et al., 1982).

These possibilities imply that there is regulation of synthesis of amylase, and possibly other secretory proteins, at the level of translation in rat parotid glands after stimulated secretion, as suggested by Grand and Gross (1970), as well as by us (Kim et al., 1989). There are many examples of the translational control of protein synthesis (Thireos, Griffin-Shea and Kafatos, 1980; Noe, 1981; Lindquist, 1981; Cordell et al., 1982). Further studies of isoproterenolstimulated rat parotids are needed to determine how the synthesis of secretory proteins is regulated. Whether the transcriptional rates of secretory proteins change after isoproterenol-stimulated secretion needs to be determined by nuclear run-on experiments. Rates of degradation of secretory protein mRNAs and the translational efficiency of these mRNAs in rat parotids after stimulated secretion should also be assessed in order to determine whether the synthesis of secretory proteins is regulated at the translational level.

Fig. 4. Northern blot of parotid RNA from young unstimulated rats (YU), old unstimulated rats (OU) and stimulated old rats $2(02), 4(04)$ and $6(06) \mathrm{h}$ after isoproterenol injection, hybridized with ${ }^{32} \mathrm{P}$-labelled amylase riboprobe. The molecular size $(1.7 \mathrm{~kb})$ of amylase mRNA is the same and the amount of the mRNA in each lane is not significantly different. 


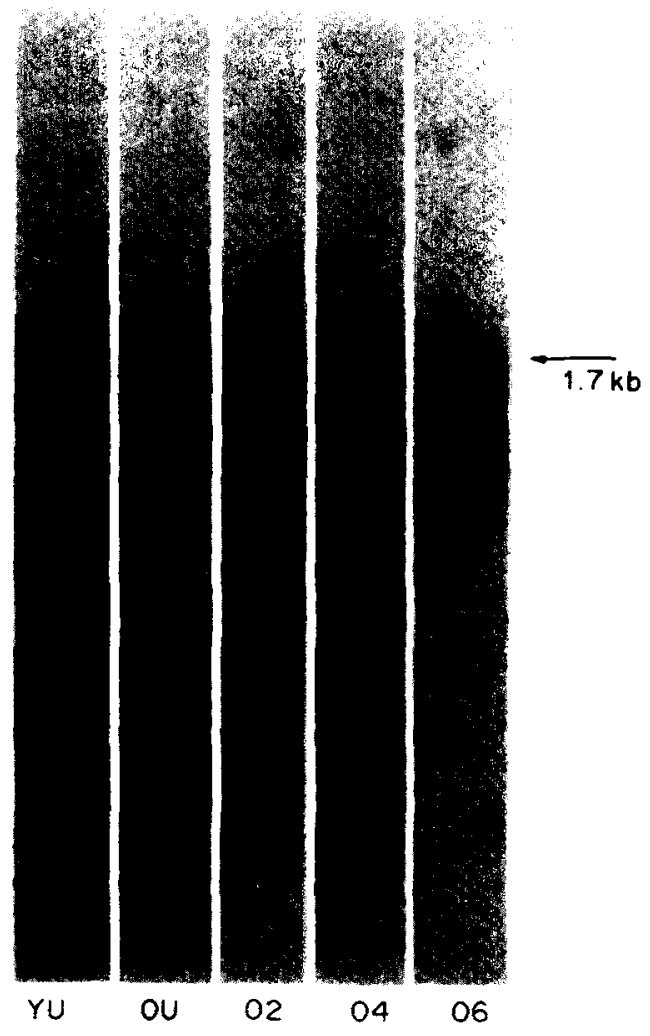


Acknowledgements-This investigation was supported in part by the Veterans Administration and by USPHS Research Grant AG-07159 from the National Institute of Aging, National Institutes of Health, Bethesda, MD 20892, I J.S.A.

\section{REFERENCES}

Amsterdam A., Ohad I. and Schram M. (1969) Dynamic changes in the ultrastructure of the acinar cell of the rat parotid gland during the secretory cycle. J. Cell Biol. 41, 753-773.

Babad S., Ben-Zvi S. R., Bdolah A. and Schramm M. (1967) The mechanism of enzyme secretion by the cell. 4. Effects of inducers, substrates and inhibitors in amylase secretion by rat parotid slices. Eur. J. Biochem. 1, 96-101.

Bdolah A. and Schramm M. (1965) The function of $3^{\prime} 5^{\prime}$ cyclic AMP in enzyme secretion by the cell. Biochem. biophys. Res. Commun. 18, 452-454.

Bernfeld P. (1955) Amylases, alpha and beta. Meth. Enzym. $1,149-158$.

Brock M. L. and Shapiro D. J. (1983) Estrogen stabilizes vitellogenin $\mathrm{mRNA}$ against cytoplasmic degradation. Cell 34, 207-214.

Burton K. (1956) A study of the conditions and mechanism of the diphenylamine reaction for the colorimetric estimation of denxyribonucleic acid. Biochem. J. 62, 315-323.

Castle J. D., Jamieson J. D. and Palade G. E. (1972) Radioautographic analyses of the secretory process in the parotid acinar cell of the rabbit. J. Cell Biol. 53, 290-311.

Chirgwin J. M., Pryzybyla A. E., MacDonald R. J. and Rutter W. J. (1979) Isolation of biologically active ribonucleic acid from sources enriched in ribonuclease. Biochemistry 18, 5294-5299.

Cordell B., Diamond D., Smith S., Punter J., Schone H. H. and Goodman H. M. (1982) Disproportionate expression of the two nonallelic rat insulin genes in a pancreatic tumor is due to translational control. Cell 31, $531-542$.

Grand R. J. and Gross P. R. (1970) Translation-level control of amylase and protein synthesis by epinephrine. Proc. natn. Acad. Sci. 65, 1081-1088.

Greenberg R. E. and Holt P. R. (1986) Influence of aging upon pancreatic digestive enzymes. Digest. Dis. Sci. 31, 970-977.

Guyette W. A., Matusik R. J. and Rosen J. M. (1979) Prolactin-mediated transcriptional and post-transcriptional control of casein gene expression. Cell 17 , 1013-1023.

Hintze J. L. (1986) Number Cruncher Statistical System, Version 4.21. Kaysville, UT.

Kim S. K. (1981) Age-related changes in the cellular level of amylase and protein synthesis in the rat parotid gland. J. dent. res. 60, 738-749.

Kim S. K. (1984) Changes in the secretory acinar cells of the rat parotid gland during aging. Anat. Rec. 209, 345-354.

Kim S. K. and Arisumi P. P. (1985) The synthesis of amylase in parotid glands of young and old rats. Mech. Aging Dev. 31, 257-266.
Kim S. K., Weinhold P. A., Han S. S. and Wagner D. J. (1980) Age-related decline in protein synthesis in the rat parotid gland. Expl Geront. 15, 7I-85.

Kim S. K., Calkins D. W., Weinhold P. A. and Han S. S. (1982) The changes in the synthesis of exportable and nonexportable proteins in parotid glands during aging. Mech. Aging Dev. 18, 239-250.

Kim S. K., Jones T. P. and Cuzzort L. M. (1989) Protein synthesis and amylase messenger RNA content in rat salivary glands after total or partial stimulation with isoproterenol. Archs oral Biol. 34, 895-901.

Kim S. K., Cuzzort L. M., McKean R. M. and Allen E. D. (1990) Effects of diabetes and insulin on alpha-amylase messenger RNA levels in rat parotid glands. $J$. dent. Res. 69, $1500-1504$.

Kozak M. (1980) Evolution of the "scanning model" for initiation of protein synthesis in eucaryotes. Cell 22, 7-8.

Lillie J. H. and Han S. S. (1973) Secretory protein synthesis in the stimulated rat parotid gland. Temporal dissociation of the maximal response from secretion. J. Cell Biol. 59, 708-721.

Lindquist S. (1981) Regulation of protein synthesis during heat shock. Nature 293, 311-314.

Lodish H. F. (1976) Translational control of protein synthesis. A. Rev. Biochem. 45, 39-72.

Loyter A. and Schramm M. (1962) The glycogen-amylase complex as a means of obtaining highly purified aamylases. Biochim. biophys. Acta 65, 201-206.

Malamud D. (1972) Amylase secretion from mouse parotid and pancreas: role of cyclic AMP and isoproterenol. Biochim. biophys. Acta 279, 373-376.

Nilsson G., Belasco J. G., Cohen S. N. and von Gabain A. (1984) Growth-rate dependent regulation of mRNA stability in Escherichia coli. Nature 312, 75-77.

Noe B. D. (1981) Synthesis of one form of pancreatic islet somatostatin predominates. J. biol. Chem. 256, 9397-9400.

Palade G. E. (1975) Intracellular aspects of the process of protein synthesis. Science 189, 347-358.

Poulsen K., Jakobsen B. K., Mikkelsen B. M., Harmark K., Nielsen J. T. and Hiorth J. P. (1986) Coordination of murine parotid secretory protein and salivary amylase expression. $E M B O J l 5,1891-1896$.

Przybyla A. E., MacDonald R. J., Harding J. D., Pictet R. L. and Rutter W. J. (1979) Accumulation of the predominant pancreatic mRNA during embryonic development. J. biol. Chem. 254, 2154-2159.

Richardson A. (1981) The relationship between aging and protein synthesis. In C.R.C. Handbook of Biochemistry in Aging (Ed. Florini J. R.), p. 79-101. CRC Press, Boca Raton, FL.

Sambrook J., Fritsch E. F. and Maniatis T. (1989) Molecular cloning. A Laboratory Manual, 2nd edn. Cold Spring Harbor Laboratory Press, New York, NY.

Shaw P., Sordat B. and Schibler U. (1986) Developmental coordination of a-amylase and Psp gene expression during mouse parotid gland differentiation is controlled posttranscriptionally. Cell 47, 107-112.

Thireos G., Griffin-Shea R. and Kafatos F. C. (1980) Untranslated mRNA for a chorion protein of Drosophila melanogaster accumulates transiently at the onset of specific gene amplification. Proc. natn. Acad. Sci. 77, $5789-5793$. 